\title{
COMENTARIOS DE LIBROS
}


Libro : "Psicobiografía de Pablo Neruda (Identidad Psicosocial y Creación Poética)"

Autor : Luis Rubilar S.

Editorial : Universidad de Santiago de Chile/Instituto de Estudios Avanzados

Ciudad : Santiago de Chile 2003

Este trabajo interpretativo acerca de la vida y génesis de la producción poética de Neruda, a través de un enfoque psicodinámico ("psicoanalítico" y "psicohistórico", pag 13), nos aporta una recopilación y análisis de la obra de Neruda, sobre la base de un minucioso trabajo de tesis, donde sin duda los datos biográficos nos permiten, desde una perspectiva psicoanalítica, encontrar una serie de eslabones entre su palabra poética y el significado metafórico-simbólico, relacionados con su vida misma. Como sostiene Rubilar; "interpretamos así la constitución del sujeto y actor social como proceso intersubjetivo, cosubtanciado con las circunstancias de su vida (o su mundo). Tal proceso y constructo se instituyen, a su vez, como soporte desde el que enuncia su discurso autobiográfico, a través de el cual múltiples voces se congregan en torno a la objetivación escrita de las profundas raíces psicosociales e históricoculturales de su identidad personal y social (pág 13).

Los capítulos I y II introducen a esta obra dejando entrever todo el enfoque humanista con que el autor abordará el análisis posterior. Es un libro que cautiva desde sus ini- cios, constituyéndose en una rica fuente de datos históricos y sociales, dando cuenta de nuestra identidad poética.

Al definirse desde el inicio como un estudio de caso, fundamenta desde sus orígenes la validez de este estudio cualitativo, formulando tesis proposicionales (pag 71) de la vida poesía nerudiana más que hipótesis.

Sus críticas al nuevo código (pag 34) electrónico-visual sobre la fragmentación de las identidades, no van en detrimento de la formulación de una propuesta investigativa, sobre la base de que seamos nosotros los que nos decidamos a usar la informática y no terminar siendo utilizados por ésta.

La forma en que describe su revisión bibliográfica, se constituye en sí misma en un método de ayuda al lector que requiera de fuentes bastante completas y actualizadas sobre el poeta.

M.Verónica Garay Psicóloga

Unidad de Salud Mental Hospital de Quillota 
